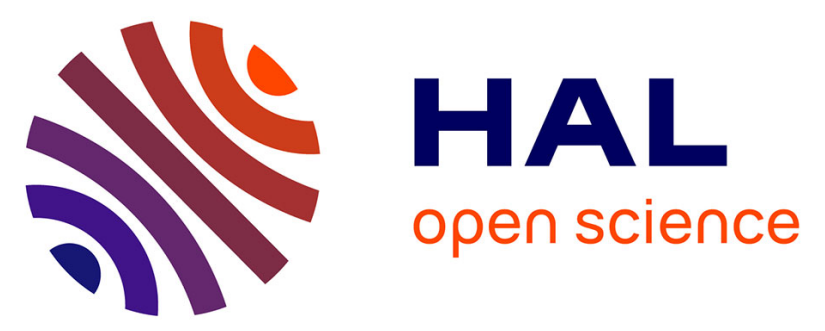

\title{
The first representative of the fly genus Trentepohlia subgenus Mongoma in amber from the Miocene of Sumatra (Diptera: Limoniidae)
}

\author{
Valerie Ngô-Muller, Romain Garrouste, Jean-Marc Pouillon, Vigo \\ Christophersen, Arne Christophersen, André Nel
}

\section{To cite this version:}

Valerie Ngô-Muller, Romain Garrouste, Jean-Marc Pouillon, Vigo Christophersen, Arne Christophersen, et al.. The first representative of the fly genus Trentepohlia subgenus Mongoma in amber from the Miocene of Sumatra (Diptera: Limoniidae). Historical Biology, In press, 10.1080/08912963.2019.1610948. hal-02374681

\section{HAL Id: hal-02374681 \\ https://hal.sorbonne-universite.fr/hal-02374681}

Submitted on 21 Nov 2019

HAL is a multi-disciplinary open access archive for the deposit and dissemination of scientific research documents, whether they are published or not. The documents may come from teaching and research institutions in France or abroad, or from public or private research centers.
L'archive ouverte pluridisciplinaire HAL, est destinée au dépôt et à la diffusion de documents scientifiques de niveau recherche, publiés ou non, émanant des établissements d'enseignement et de recherche français ou étrangers, des laboratoires publics ou privés. 
The first representative of the fly genus Trentepohlia subgenus Mongoma in amber from the Miocene of Sumatra (Diptera: Limoniidae)

Valerie Ngô-Muller ${ }^{\mathrm{a}, \mathrm{b}}$, Romain Garrouste ${ }^{\mathrm{b}}$, Jean-Marc Pouillon ${ }^{\mathrm{c}}$, Vigo Christophersen ${ }^{\mathrm{d}}$, Arne Christophersen ${ }^{\mathrm{d}}$ and Andre $\mathrm{Nel}^{\mathrm{b}}$

a UFR Sciences du Vivant, Université Paris Diderot, Sorbonne Paris Cité, F-75013 Paris, France.E-mail: valerie.ngo-muller@univ-paris-diderot.fr

b Institut de Systématique, Évolution, Biodiversité, ISYEB - UMR 7205 - CNRS, MNHN, UPMC, EPHE, Muséum national d'Histoire naturelle, Sorbonne Universités, 57 rue Cuvier, CP 50, Entomologie, F-75005, Paris, France.

${ }^{\mathrm{c}} 178$ rue des Plattieres, F-38300 Nivolas Vermelle, France.

d Starborn Creations, 105 Portal Lane, 86336 Sedona, Arizona, USA.

\section{ABSTRACT}

The limoniid fly Trentepohlia (Mongoma) pouilloni n. sp. Ngô-Muller, Garrouste \& Nel, is the first fossil insect to be described from Sumatra. On the basis of its wing morphology and venation, it is very similar to the extant Sumatran species Trentepohlia (Mongoma) pennipes (Osten Sacken, 1888), supporting a Miocene rather than older age for the amber. By comparison with the few available data on the biology of the extant species of the subgenus Mongoma, it probably lived in a warm and humid forest where it was trapped in dipterocarpacean resin. The wide Cenozoic distribution of the subgenus Mongoma in Europe and South-East Asia is in accordance to its extant circumtropical distribution.

\section{KEYWORDS}


Insecta; Diptera; Tipuloidea; n. sp.; Sumatra amber

\section{Introduction}

The limoniid flies are very frequent in the fossil record (see Fossilworks internet site at http://fossilworks.org/). The family is supposed to be dated from Late Triassic (Blagoderov et al. 2007). They are frequently found as compression fossils or inclusions in amber. Their larvae are either aquatic or terrestrial living in fungi, decayed vegetation, plant roots, etc. Among them, the extant genus Trentepohlia Bigot, 1854 is one of the largest genera with more than 300 species distributed on all continents except Antarctica. It is currently subdivided into seven extant subgenera plus an Eocene one (Podenas 2003; Evenhuis 2014; Oosterbroek 2019). It is quite old as a species: Trentepohlia (Paramongoma) dzeura was described from Burmese amber (100 Myrs old) (Podenas \& Poinar 2009). Fossils of subgenera Trentepohlia Bigot, 1854, Paramongoma Brunetti, 1911, Mongoma Westwood, 1881, and Onutia Podenas, 2003 are known.

Here we describe the first fossil species of the subgenus Mongoma in amber, found in the Sumatra Miocene. Two species, T. (M.) cruciferella Cockerell, 1917 and T. (M.) pallescens Cockerell, 1921, attributed to this subgenus were previously described from the lacustrine Eocene - Oligocene of the Isle of Wight (UK) (Cockerell 1921).

Gayet (1991) cited the presence of fossil insects in a Cenozoic lacustrine outcrop near Padang in Sumatra but no fossil was ever studied or even collected. Thus the present fossil is the first fossil insect to be described from Sumatra. It is a part of a small collection of amber pieces with inclusions bought from a local trader (Starnborn Creations). Many Coleoptera: Platypodidae are also present in our material from the same amber. Interestingly Bąk et al. (2016) cited the presence of Ambrosiella-like fungi from the amber from Jambi mine, adding 
that such fungi are frequently associated to scolytid or platypodid beetles that attack the tree trunks.

\section{Material and methods}

The present specimen is preserved in a piece of relatively clear, yellow amber, without syninclusions, which was ground and polished prior to examination and photography.

Brackman et al. (1984) first studied fossil resins from the Miocene of Sumatra. These fossil resins are of Glessite type and were probably produced by trees of the family Dipterocarpaceae, likely close to Shorea. Narudeesombat et al. (2014) and Naglik et al. (2018) confirmed this family origin. Messer (1990) indicated that resin exudate by the dipterocarpacean Shorea javanica is locally exploited. Leelawatanasukand et al. (2013) also cited the existence of Sumatra amber. Sumatra amber is a byproduct of coal mining. Eocene to Pliocene coal mines with amber were recorded (Belkin \& Tewalt 2007; Bąk et al., 2016). Narudeesombat et al. (2014) were the first to figure an undetermined insect from the Oligocene-Miocene amber of the Central Sumatra Basin.

Our material comes from the South Sumatra Basin, probably from Sinamar, Dharmasraya Regency, West Sumatra (De Smet \& Barber, 2005). Numerous amber inclusions are deformed because of amber was probably heated by volcanic activity that occurred in the area during the Miocene (Kosmowska-Ceranowicz et al. 2017).

The fossil was studied and measured using incident and transmitted light with stereomicroscopes (Olympus SZX9 and Nikon SMZ 1500). Images were digitally compiled using Helicon Focus software, and arranged using Adobe Photoshop software. The taxonomic actions established in the present work are registered in ZooBank, and with the publication urn:lsid:zoobank.org:act:B216AE76-FC1F-44CD-A892-2EF3FF6DE041 
We followed the catalogue of the Tipuloidea of Oosterbroek (2019) to obtain the World list of extant Mongoma spp. We followed wing venation nomenclature of Cumming \& Wood (2017) and classification of the Limoniidae of Starý (1992), also followed by Petersen (2006).

Systematic palaeontology

Order Diptera Linnaeus, 1758

Family Limoniidae Rondani, 1856

Genus Trentepohlia Bigot, 1854

Subgenus Mongoma Westwood, 1881

Type species. Mongoma fragillima Westwood, 1881.

Trentepohlia (Mongoma) pouilloni Ngô-Muller, Garrouste \& Nel, n. sp. (Figures 1-2)

Etymology. Named after Mr. J.-M. Pouillon, who helped us a lot in our studies on fossil insects.

Material. Holotype JMP 2365, stored in collection Jean-Marc Pouillon.

Diagnosis. Wing characters only. Wing hyaline, $8 \mathrm{~mm}$ long; Rs twice as long as r-m; R2 distinctly shorter than R3; part of Rs distal of base of R2 present, but distinctly shorter than R2; base of M3 distinctly distal of that of M2; cell dm more than three times as long as wide; m-cu more basal than basal side of $\mathrm{dm}$; $\mathrm{CuA}$ and $\mathrm{CuP}$ fused distally, forming a short but distinct vein $\mathrm{CuA}+\mathrm{CuP}$; cell cua broader than cell bm. 
Description. Body dark, well preserved, except for the missing apex of abdomen; thorax hardly visible because of infuscate amber, head $0.75 \mathrm{~mm}$ wide, antennae $2.5 \mathrm{~mm}$ long; wing characters: halter long, $1.2 \mathrm{~mm}, 0.2 \mathrm{~mm}$ wide; preserved part of abdomen $3.6 \mathrm{~mm}$ wide. Preserved part of wing $7.2 \mathrm{~mm}$ long, wing probably ca. $8.0 \mathrm{~mm}$ long, $1.6 \mathrm{~mm}$ wide; hyaline except for a brown elliptic pterostigma, $0.8 \mathrm{~mm}$ long, $0.2 \mathrm{~mm}$ wide; sc-r present far from $\mathrm{Sc}$ apex, Sc ending on costa $0.4 \mathrm{~mm}$ basal of apex of $\mathrm{R} 1+2$; distance between the point where $\mathrm{R} 2$ ends on R1 and apex of R1+2 $0.5 \mathrm{~mm}$; Rs separating from R1 $2.5 \mathrm{~mm}$ from wing base; distance between base of Rs and r-m $1.3 \mathrm{~mm}$; r-m $0.68 \mathrm{~mm}$ long, aligned with basal part of Rs; length of part of Rs between r-m and base of R2 1.7 mm; R2 oblique, 0.4 mm long; R3+4 very short but distinct, $0.1 \mathrm{~mm}$ long; R3 longer than R2, $0.9 \mathrm{~mm}$ long; R4 longer than R3, ca. $1.9 \mathrm{~mm}$ long; length of basal stem of M $3.3 \mathrm{~mm}$; length of basal side of cell $\mathrm{dm} 0.2 \mathrm{~mm}$; anterior side of cell $\mathrm{dm} 0.7 \mathrm{~mm}$ long, posterior side of cell $\mathrm{dm} 0.9 \mathrm{~mm}$ long, the two points of separations of M1 and M2 and of M3 and M4 are at the same level; dm 3.5 times as long as wide, $1.0 \mathrm{~mm}$ long and $0.3 \mathrm{~mm}$ wide; basal part of $\mathrm{M} 3$ short and curved; distal parts of $\mathrm{M} 1$, M2, M3 and M4 straight; m-cu slightly basad to basal side of cell dm; CuA strongly curved distal of m-cu and ending into $\mathrm{CuP}$; $\mathrm{CuA}+\mathrm{CuP} 0.2 \mathrm{~mm}$ long; cell cua between $\mathrm{CuA}$ and $\mathrm{CuP}$ broad, broader than cell bm and as broad as cell br; A1 making a strong sigmoidal curve, ending on posterior wing margin $2.4 \mathrm{~mm}$ basal of apex of $\mathrm{CuA}+\mathrm{CuP}$; $\mathrm{A} 2$ a small arched vein.

\section{Discussion}

The wing venation of this fly is typical of the limoniid genus Trentepohlia Bigot, 1854, subgenus Mongoma Westwood, 1881 on the basis of the following characters, modified after Petersen (2006): Sc long, sc-r far from Sc apex, Sc ending after split of Rs; part of R1 distal of point of fusion of R2 with R1, subequal to R2, R2 typically directed toward wing base and ending into R1; two branches of Rs (R3, R4) attaining wing margin, R3 and R4 strongly 
divergent; r-m crossvein at antero-basal angle of cell $\mathrm{dm}$ and aligned with basal part of Rs; four medial veins (M1, M2, M3, M4) attaining wing margin; M4 aligned with basal part of M; cell $\mathrm{dm}$ present; $\mathrm{CuA}$ intersecting $\mathrm{CuP}$ near posterior wing margin, thus cell cua is closed; one anal vein A1 attaining wing margin.

Mongoma is the most species-rich worldwide subgenus of Trentepohlia, with 145 described species (Oosterbroek 2019). It is very well represented in the Oriental region, but also present in Afrotropical, Australasian / Oceanian, East Palaearctic, and Neotropical regions. There is currently no phylogenetic analysis of Trentepohlia and no extensive revision of Mongoma. If Oosterbroek (2019) placed this genus in the Limoniinae, Petersen (2008) considered it as being of 'unplaced position' in the Limoniidae. Thus we should compare our fossil with extant species of Mongoma, which is currently clearly not feasible because many species have never been revised since their original descriptions. In fact the entire subgenus urgently needs a revision. Lack of information on the terminalia of our fossil and of some extant species also renders the comparison very delicate. Nevertheless we have compared a set of 10 wing characters (see Supplementary table 1) between our fossil and the extant Mongoma spp. from the Oriental region (see Supplementary tables 2-3). The value of these characters is even questionable, since the venation within a single species of Limoniidae may greatly vary (see Alexander \& Leonard 1912). In table 2, some characters could not be coded for certain taxa, being absent in the original description. In fact, we could completely fill in the lines of the taxa for which a figure of the venation was given in the literature. Thus 21 taxa are incompletely filled, while 42 are completely informed for the defined set of characters. Among them, Trentepohlia (Mongoma) pouilloni n. sp. shares nine character states with only one taxon T. (M.) pennipes, the unique difference being 'cell cua broader than cell bm' (Podenas et al. 2015). This continuous character could be due to taphonomic deformation of the fossil, a situation rather frequent for the structures of the insects included in the Sumatra 
amber. Nevertheless, three other extant Mongoma spp. from the Oriental region also share the same state of character present in T. (M.) pouilloni n. sp. (see table 2). The other extant taxa differ from T. (M.) pouilloni n. sp. in at least three character states. T. (M.) pennipes is supposed to be present in a very wide area, including Mozambique (Africa), Seychelles (Indian Ocean), China, Korea, Philippines, India, Malaysia, Papua New Guinea Indonesia (including Sumatra) (Oosterbroek 2019). Thus T. (M.) pouilloni n. sp. is possibly closely related to T. (M.) pennipes present in the same island.

Cockerell (1917) described and partly figured a wing (compression fossil) that he attributed to the subgenus Mongoma, T. (M.) cruciferella Cockerell, 1917 from the Latest Eocene of the Isle of Wight (Gurnet Bay). Its wing is $5.0 \mathrm{~mm}$ long, and differs from that of T. (M.) pouilloni n. sp. in the absence of a stem of R3+4. Cockerell (1921) described another species T. (M.) pallescens Cockerell, 1921 from the same outcrop. It differs from T. (M.) pouilloni n. sp. in wings $4.0 \mathrm{~mm}$ long, $\mathrm{m}$-cu aligned with basal side of $\mathrm{dm}$, and a shorter R3.

\section{Conclusion}

T. (M.) pouilloni n. sp. seems to be very closely related to the extant species T. (M.) pennipes, suggesting a Miocene age than an Eocene one for the amber. This hypothesis needs to be tested through future study of the other embedded insects. The biology of the Mongoma spp. remains nearly unknown, however adult specimens of T. (M.) inexpectata Mederos-López \& Gelhaus, 2014 were observed in shelter cavities between tree roots in Cuba forests (MederosLópez \& Gelhaus 2014). This particular behavior may result in a higher probability of being trapped in resin. These flies probably lived in warm and humid forests, in accordance with the dipterocarpacean origin of the amber. The presence of the subgenus Mongoma in the Latest Eocene of UK and the Miocene of Sumatra suggests that it was widespread during Cenozoic period and is in accordance to its extant circumtropical distribution. 


\section{Acknowledgments}

We sincerely thank Jorge Mederos-López and an anonymous referee for their helpful remarks on the first version of the paper.

\section{Disclosure statement}

No potential conflict of interest was reported by the authors.

\section{References}

Alexander CP, Leonard MD. 1912. Venational variation in Cladura (Tipulidae Diptera). Journal of the New York Entomological Society 20:36-40.

Bąk M, Natkaniec-Nowak L, Drzewicz P, Czapla D, Ivanina AV, Bogdasarov MA. 2016. Ambrosiella-like fungi in fossil resin from Jambi Province in Sumatra Island - possible phoretic organisms interacted with invaded insects. 17th Czech-Slovak-Polish Palaeontological Conference at: Kraków:1 p.

Belkin HE, Tewalt SJ. 2007. Geochemistry of selected coal samples from Sumatra, Kalimantan, Sulawesi, and Papua, Indonesia. United States Department of the Interior, Geological Survey, Open-File Report 2007-1202:1-34.

Blagoderov VA, Grimaldi DA, Fraser NC. 2007. How time flies for flies: diverse Diptera from the Triassic of Virginia and early radiation of the order. American Museum Novitates 3572:1-39.

Brackman W, Spaargaren K, Dongen van JPCM, Couperus PA, Bakker F. 1984. Origin and structure of the fossil resin from an Indonesian Miocene coal. Geochimica et Cosmochimica Acta 48:2483-2487. 
Cockerell TDA. 1917 Descriptions of fossil insects. Proceedings of the Biological Society of Washington 30:79-82.

Cockerell TDA. 1921. Fossil arthropods in the British Museum. 6. Oligocene insects from Gurnet Bay, Isle of Wight. Annals and Magazine of Natural History (9) 7:453-480.

Cumming JM, Wood DM. 2017. Adult morphology and terminology. pp. 89-134. In: KirkSpriggs AH, Sinclair BJ. (eds). Manual of Afrotropical Diptera, Volume 1. Introductory chapters and keys to Diptera families. Suricata, Pretoria, 4:i-xiii + 1-425.

De Smet, MEM, Barber AJ. 2005. Chapter 7. Tertiary stratigraphy. In: Barber AJ, Crow MJ \& Milsom JS. (eds). Sumatra: geology, resources and tectonic evolution. Memoirs of the Geological Society, London, 31:86-97.

Evenhuis NL. 2014. Family Limoniidae, In: Catalog of the fossil flies of the world (Insecta: Diptera) (website. Available at: http://hbs.bishopmuseum.org/fossilcat/fosslimoniidae.html.) Kosmowska-Ceranowicz B, Sachanbiński M, Łydżba-Kopczyńska B. 2017. Analytical characterization of "Indonesian amber" deposits: evidence of formation from volcanic activity. Baltica 30:55-60.

Gayet M. 1991. Gisements à poissons de Sumatra (Indonésie). Fiches Grands Gisements Paléontologiques, Paléogène:2 pp.

Leelawatanasuk T, Wathanaku P, Paramita S, Sutthirat C, Sriprasert B, Bupparenoo P. 2013. The characteristics of amber from Indonesia. The Australian Gemmologist 25:142-145.

Mederos-López J, Gelhaus JK. 2014. A new Neotropical species of Trentepohlia (Mongoma) (Diptera: Tipulidae) from Cuba. Transactions of the American Entomological Society $140: 137-144$.

Messer AC. 1990. Traditional and chemical techniques for stimulation of Shorea javanica (Dipterocarpaceae) resin exudation in Sumatra. Economic Botany 44:463-469. 
Naglik B, Kosmowska-Ceranowicz B, Natkaniec-Nowak L, Drzewicz P, Dumanska-Słowik M, Matusik J, M., Milovsky R, Stach P, Szyszka A. 2018. Fossilization history of fossil resin from Jambi Province (Sumatra, Indonesia) based on physico-chemical studies. Minerals 8:114.

Narudeesombat N, Ounorn P, Bupparaenoo P, Christopherse A, Pisutha-Arnond V, Sutthirat C. 2014. Update on the characteristics of amber from Indonesia. The 4th International Gem and Jewelry Conference:271-276.

Oosterbroek P. 2019. Catalogue of the craneflies of the World (Diptera, Tipuloidea: Pediciidae, Limoniidae, Cylindrotomidae, Tipulidae). Internet site https://ccw.naturalis.nl/index.php (consulted 29/01/2019)

Petersen MJ. 2006. Key to the adult crane flies of the Oriental region. Version 2.0. http://www. ent. iastate. edu/dept/research/systematics/thai/tipuloidea/key/adult

Petersen MJ. 2008. A systematic investigation of the crane fly subfamily Limoniinae (Tipuloidea: Limoniidae). Retrospective Theses and Dissertations, University of Iowa, 15829:1-320.

Podenas S. 2003. A new subgenus for Trentepohlia crane flies (Diptera: Limoniidae) with elongated mouth parts, from Baltic amber (Eocene). Proceedings of the Academy of Natural Sciences of Philadelphia 153:67-71.

Podenas S, Byun HW, Kim SK. 2015. New Dicranioptycha Osten Sacken, 1859 crane flies (Diptera: Limoniidae) of North and South Korea. Zootaxa 3925:257-270.

Podenas S, Poinar GO. 2009. New crane flies (Diptera: Limoniidae) from Burmese amber. Proceedings of the Entomological Society of Washington 111:470-492.

Starý J. 1992. Phylogeny and classification of Tipulomorpha, with special emphasis on the family Limoniidae. Acta Zoologica Cracoviencia 35:11-36. 
Figure 1. Trentepohlia (Mongoma) pouilloni n. sp. Ngô-Muller, Garrouste \& Nel, holotype JPM 2365. A, general habitus (scale bar: $1 \mathrm{~mm}$ ); B, fore wing (scale bar: $2 \mathrm{~mm}$ ).

Figure 2. Trentepohlia (Mongoma) pouilloni n. sp. Ngô-Muller, Garrouste \& Nel, holotype JPM 2365. Head (scale bar: $1 \mathrm{~mm}$ ). 
